\title{
Interaksionisme Simbolik Pasangan Suami-Isteri Ketika Berada di Media WhatsApp (WA)
}

\author{
Puri Kusuma Dwi Putri \\ purikdp@yahoo.com
}

\begin{abstract}
ABSTRAK
Komunikasi antarpribadi secara intensif antara pasangan suami-isteri sudah bukan menjadi suatu hal yang penting dalam kehidupan rumah tangga ketika kehadiran media sosial semakin banyak, maju dan berada di genggaman individu modern. Sering dijumpai bahwa pada waktu pasangan (suami atau isteri) lebih banyak untuk chatting dengan teman-teman melalui media sosial salah satunya dengan WhatsApp (WA). Walaupun telihatnya chatting melalui handphone dengan Pria Idalam Lain (PIL) atau Wanita Idaman Lain (WIL), hal itu tentunya menimbulkan kecemburuan, konflik hingga perceraian dengan pasangan Tulisan ini menggunakan study literature. Teori interaksi simbolik (Symbolic Interaction Theory) menekankan pada hubungan antara simbol dan interaksi yang diberi nama Mind, Self, and Society, gejala perubahan sosial dari perspektif teori interaksi dapat dilihat bahwa pasangan suami-isteri yang semakin dalam berinteraksi melalui WA dengan PIL atau WIL akan membuat ketahanan keluarga terancam dan kepercayaan keduanya dapat menurun, serta kontribusi teori komunikasi dalam perspektif teori interaksi yakni Mead menyebut looking-glass-self dan konsep diri yang dihasilkan melalui interaksi.
\end{abstract}

Kata kunci: media sosial, chatting, WhatsApp, pasangan

\section{Symbolic Interactionism between Married Couple in WhatsApp}

\begin{abstract}
Intensive interpersonal communication between husband and wife has no longer become an important part domestic life following the advancement social media in the life the modern individual. Often found that when a couple (husband or wife) has more time to chat with friends using social medias. WhatsApp (WA) is one of them. In other case, chatting with affairs would cause jealousy, conflict or even divorce. The research of this paper uses literature study. Symbolic Interaction Theory emphasizes the relationship between symbols and interaction named Mind, Self, and Society. Symptoms of social change from perspective interaction theory tell that the couples who are increasingly interacting with affairsvia WhatsApp would have their marriage threatened. Moreover, the contribution of communication
\end{abstract}


theory in theperspective of interaction theory of Mead mentioned the looking-glassself and the concept of self are generated through interaction.

Keywords: social media, chat, WhatsApp, couple

\section{PENDAHULUAN}

\section{LATAR BELAKANG}

Kehadiran media sosial dengan cepat merubah penjadwalan aktifitas audiens. Setelah bangun tidur hingga kembali tidur lagi, perilaku audiens lebih memilih untuk terkoneksi dengan internet terlebih dahulu melalui handphone, kemudian melihat hal update apa di dunia cyber yang sudah terjadi, status teman, dan berita. Kehidupan virtual sudah menjadi candu di dalam aktifitas sehari-hari bagi tua, muda, bahkan dalam kehidupan rumah tangga.

Selain melalui gadget, mudahnya akses internet di berbagai ruang publik dengan wi fi ikut meramaikan era virtual masa kini. Di mall, kampus, tempat pelayanan, rumah sakit, restoran, hotel, perpustakaan, dan lain sebagainya telah menyediakan fasilitas wi fi. Justru ketika ruang publik tidak mempunyai fasilitas wi fi akan dianggap ketinggalan zaman dan tidak up to date. Beberapa waktu lalu seorang teman upload gambar yang isi pesannya berupa pemberitahuan dari suatu

café di Jerman bahwa café tersebut tidak menyediakan wi fi, agar para konsumen berinteraksi face to face tanpa terganggu dengan kesibukan konsumen melalui gadgetnya. Adanya kehadiran berbagai paket pulsa internet juga ikut mendukung perkembangn tekhnologi komunikasi dalam genggaman.

Perkembangan teknologi komunikasi dan internet membawa kehadiran cyber sekaligus menciptakan masyarakat cyber di dalamnya. Masyarakat cyber menjadi masyarakat penikmat segala rasa. Internet sudah berada dalam genggaman ketika kita berada di rumah, kantor, dan di mana kita berada. Perkembangan tersebut merubah pula gaya hidup yang semakin virtual dan digital hingga dapat menggeser komunikasi dalam rumah tangga yang awalnya intim dapat menjadi renggang. Awalnya pasangan dapat meluangkan waktu untuk berkomunikasi lebih dalam, 
tetapi dapat menjadi jarang bertatap muka dan berkomunikasi akibat dampak WhatsApp (WA).

Komunikasi antar pribadi secara intens terkadang sudah bukan menjadi suatu hal yang penting dalam kehidupan rumah tangga ketika kehadiran media sosial semakin banyak, maju dan berada di genggaman hampir tiap individu yang modern. Sering dijumpai bahwa pada waktu pasangan (suami atau isteri) lebih banyak untuk chatting dengan teman-teman melalui media sosial. Dahulu budaya makan bersama di dalam suatu meja makan yang mana sebagai tempat berinteraksi dan berbagi makna dengan anggota keluarga menjadi salah satu media efektif secara tatap muka untuk semakin intim dan mengenal pribadi masing-masing anggota keluarga, tetapi ironisnya budaya itu semakin menipis dengan kehadiran gadget. Kehadiran gadget mengurangi interaksi komunikasi langsung, anggota keluarga lebih asyik dengan cyber media melalui gadget.

“Sosial media meningkatkan perselingkuhan di Italia, karena jadi memudahkan. Pertama pesan pendek, kemudian Facebook, kini WhatsApp, yang sekarang banyak dipakai pasangan yang berhubungan secara sembunyi," kata Presiden Asosiasi, Gian Ettore Gassani kepada The Times. Berdasarkan Journal of Cyberpsychology, Behavior and Social Networking menyatakan bahwa adanya kecemburan yang terjadi pada individu yang menggunakan sosial media terlalu sering, serta dapat juga berselingkuh karena terkonesksi dengan mantan kekasih akibat penggunaan Facebook (http:/ / teknologi.metrotvnews.com/read/2014/11/11/317228/40-kasusperceraian-seret-whatsapp-ke-ruang-sidang, diakses pada tgl. 29 Mei 2015, pkl. 16. $38)$.

Ketika suami atau isteri dalam mengirim pesan-pesan melalui WA kepada orang lain melakukan suatu interaksi simbolik. Adanya emoticon untuk lawan bicara, bercanda, dan hal-hal rahasia lain yang belum tentu diketahui oleh pasangannya. Sehingga, hal itu menunjukkan suatu perubahan sosial di dalam pasangan suamiisteri, dahulu ketika WhatsApp tidak ada, tidak ada kecemburuan melalui gadget dan waktu bersama keluarga dalam berinteraksi lebih banyak, sebaliknya dampak penggunaan WhatsApp dapat menimbulkan suatu perubahan sosial diantaranya 
konflik, kurangnya komunikasi antarpribadi, kurangnya empati, kurangnya mendengarkan, dan lain sebagainya.

\section{RUMUSAN MASALAH}

Komunikasi antar pribadi secara intens terkadang sudah bukan menjadi suatu hal yang penting dalam kehidupan rumah tangga ketika kehadiran media sosial semakin banyak, maju dan berada di genggaman. Sering dijumpai bahwa pada waktu pasangan (suami atau isteri) lebih banyak untuk chatting dengan temanteman melalui media sosial salah satunya dengan WA. Chatting suami atau isteri juga melakukan interaksi simbolik dengan lawan jenis. Walaupun telihatnya chatting melalui handphone, hal itu mudah menimbulkan kecemburuan, konflik dan hambatan pada komunikasi antarpribadi. Berangkat dari permasalahan tersebut, mucul pertanyaan, bagaimana interaksionisme simbolik pasangan suami-isteri dengan lawan bicaranya melalui WhatsApp?

\section{TUJUAN}

Tujuan dari penulisan makalah ini untuk:

1. Mengetahui teori-teori interaksi dan perkembangannya

2. Gejala perubahan sosial dari perspektif teori interaksi

3. Kontribusi teori-teori komunikasi dalam perspektif teori interaksi

\section{METODOLOGI}

Metoda dalam makalah ini menggunakan studi literatur atau desk study. Studi literatur diperoleh dengan menggunakan studi pustaka berupa buku-buku, jurnal dan melalui internet.

\section{PEMBAHASAN}

\section{Teori-Teori Interaksi dan Perkembangannya}

Teori Interaksi Simbolik (Symbolic Interaction Theory) yang popular dengan "Mind, Self, and Society" (Pikiran, Diri, dan Masyarakat) mengenai hubungan antara simbol dan interaksi. Ralph Larossa dan Donald C. Reitzes (1993) dalam West \& Turner 2008) mengatakan bahwa interaksi simbolik adalah "pada intinya...sebuah 
kerangka referensi untuk memahami bagaimana manusia, bersama dengan orang lainnya, menciptakan dunia simbolik dan bagaimana dunia ini, sebaliknya, membentuk perilaku manusia". Dalam pernyataan ini, kita dapat melihat argumen Mead mengenai saling ketergantungan antara individu dan masyarakat. Pada kenyataannya, interaksi simbolik membentuk sebuah jembatan antara teori yang berfokus pada individu-individu dan teori yang berfokus pada kekuatan sosial. Kenneth L. Smith dan Linda Liska Belgrave berargumen bahwa masyarakat dibuat menjadi "nyata" oleh interaksi individu-individu, yang "hidup dan bekerja untuk membuat dunia sosial mereka bermakna". Individu dilihat aktif dan reflektif dalam suatu konteks sosial (West \& Turner 2008).

Interaksionisme Simbolis (IS) fokus terhadap bagaimana percakapan dimaknai dan disusun. Menurut Barbara Ballis Lal dasar-dasar pemikiran IS sebagai berikut (Littlejohn 2009):

- Penemuan diri manusia berasal dari keputusan dan tindakan.

- Proses-proses interaksi berada di dalam kehidupan sosial.

- Melaui makna-makna yang dipertukarkan suatu pengalaman dapat dipahami yang juga ditemukan dalam simbol-simbol dan bahasa.

- Dunia terbentuk dari obyek-obyek sosial yang memiliki nama dan makna yang ditentukan secara sosial.

- Tindakan manusia didasarkan pada penafsiran mereka.

- Interaksi sosial dengan orang lain sebagai pondasi dari diri seseorang.

Pendiri IS adalah George Herbert Mead yang menyatakan tiga konsep dalam teori Mead yaitu masyarakat, diri sendiri, dan pikiran. Di dalamnya terdapat aspekaspek yang berbeda yang disebut tindak sosial. Tindak sosial di dalamnya terdapat kesatuan tingkah laku. Sebuah tindak sosial melibatkan sebuah hubungan dari tiga bagian: gerak tubuh awal dari salah satu individu, respons dari orang lain terhadap gerak tubuh tersebut, dan sebuah hasil yang menghasilkan pelaku komunikasi. Makna terdapat di dalam ketiga hal tersebut. Sebuah perampokan merupakan hasil di mana korban memberikan uang atau barang yang diminta paksa oleh perampok (Littlejohn 2009). 
Menurut Blumer pola-pola stabil dan selalu berulang yang memiliki makna yang umum dan tetap bagi pelaku di dalam tindakan bersama (joint action). Tindakan bersama (joint action) yang terdiri antara dua orang atau lebih terjadi pada pernikahan, perdagangan, perang atau kebaktian. Dalam tindakan bersama terdapat sebuah hubungan (interlinkage) yang bemula dari interaksi sebelumnya. (Littlejohn 2009).

Pertama, mengenai masyarakat (society) atau kehidupan menurut Mead yaitu perilaku kooperatif anggota-anggotanya. Dalam berinteraksi kita mampu untuk memahami tindakan orng lain dan sebaliknya dapat mengetahui hal apa yang akan kita lakukan. Tanpa adanya kerjasama orang lain tidak mampu untuk memahami maksud orang lain (Littlejohn 2009).

Dalam komunikasi tercipta pemaknaan yang penting untuk dipahami satu sama lain. Pemaknaan yang kita terima merupakan hasil dari interaksi dengan orang lain. Melalui pemaknaan seseorang mampu menafsirkan apa yang terjadi di sekitarnya. Menurut Eli Dresdner komunikasi dilakukan melalui berbagai makna dan pertukaran simbol yang digunakan oleh individu (Blumer 1969 dalam Littlejohn 2009).

Kedua, kegiatan saling memengaruhi antara merespons pada orang lain dan diri sendiri. Seseorang dapat merasakan segala perasaan dengan dirinya seperti rasa bangga, bahagia, dan keberanian. Pengambilan peran atau melihat dengan sudut pandang orang lain dapat menghasilkan konsep diri. Konsep diri merupakan generalized others (refleksi umum orang lain) yang dapat memandang diri kita sendiri. Reaksi dari orang lain sangat penting bagi diri kita yang dilakukan melalui interaksionisme simbolis (Littlejohn 2009).

Diri terbagi dua yang masing-masing mempunyai fungsi. I merupakan bagian diri menurut kata hati, tidak teratur, tidak tearah, dan tidak dapat ditebak. Me adalah refleksi umum orang lain yang terbentuk dari pola-pola yang teratur dan tetap, yang dibagi dengan orang lain. Tindakan kita dimulai dari $I$, sedangkan yang mengendalikan adalah Me (Littlejohn 2009). 
Me adalah bagian reflektif. Me mencerminkan pada $I$, melalui refleksi diri seperti tindakan atas dasar emosi rasa malu, bangga, dan menyesal. Kita bebas mempunyai tujuan ingin menjadi seperti apa pada diri kita (Wood 2013).

Selanjutnya, konsep ketiga Mead yaitu berpikir (mind). Berpikira bagian dari tindakan mansuia yang melipatkan raguan (menunda tindakan yang jelas) ketika Anda menafsirkan situasi.Untuk menamai objek digunakan simbol-simbol yang berbeda. Bagaimana Anda bertindak berasal dari pemaknaan dari sesuatu hal yang berhubungan (Littlejohn, 2009).s

\section{Gejala Perubahan Sosial Dari Perspektif Teori Interaksi}

Berikut ini adalah jumlah prinsip dasar teori dari tokoh IS (Ritzer \& Goodman 2004):

a. Manusia merupakan makhluk yang berpikir.

b. Melalui interaksi sosial kemampuan berpikir terbentuk.

c. Arti dan simbol dipelajari dalam interaksi sosial.

d. Penafsiran terhadap situasi berasal dari makna dan simbol ketika berinteraksi.

e. Kebijakan modifikasi dan perubahan dibuat oleh manusia karena kemampuannya dalam berinteraksi dengan dirimereka sendiri.

f. Kelompok dan masyarakat dibentuk dari pola tidnakan dan interaksi satu sama lain.

Proses saling memengaruhi berasal dari interaksi sosial oleh para aktor. Ketika berinteraksi dengan orang lain, pemaknaan disampikan secara simbolik dengan orang yang terlibat. Penafsiran berdasarkan atas simbol yang dipertukarkan dan dengan mengorientasikan tindakan balasan (Ritzer \& Goodman 2004).

\subsection{Kontribusi Teori-Teori Komunikasi dalam Perspektif Teori Interaksi}

Ralph La Rose dan Donald C.Reitzes (1993) dalam West \& Turner (2008) telah mempelajari teori interaksi simbolik yang berhubungan dengan kajian mengenai keluarga. Berikut ini tujuh asumsi mendasari interaksi simbolik dan bahwa asumsiasumsi ini memperlihatkan tiga tema besar:

- Pentingnya makna bagi perilaku manusia 
- Pentingnya konsep mengenai diri

- Hubungan antar individu dengan masyarakat

\section{Pentingnya Makna Bagi Perilaku Manusia}

Teori interaksi simbolik fokus terhadap pembentukan makna melalui proses komunikasi. Dalam interaksi simbolik bertujuan untuk menciptakan makna yang sama. Komunikasi akan menjadi sulit, apabila tidak ada makna ang sama. Menurut LaRossa dan Reitzes, tema ini mengandung tiga asumsi interaksi simbolik yang diambil karya Herbert Blumer dengan asumsi-asumsi sebagai berikut (West \& Turner 2008):

- Manusia bertindak terhadap manusia lainnya berdasarkan makna yang diberikan orang lain pada mereka.

Makna berasal dari simbol yang berasal dari interaksi sosial dan perlu adanya kesepakatan dalam menerapkan makna tertentu. Contohnya, di Amerika Serikat kita umumnya menghubungkan cincin perkawinan dengan cinta dan komitmen. Cincin adalah simbol ikatan resmi dan emosional, dan karenanya kebanyakan orang menghubungkan simbol ini dengan konotasi yang positif.

- Makna diciptakan dalam interaksi antarmanusia.

Blumer menjelaskan bahwa terdapat tiga cara untuk menjelaskan asal sebuah makna diantaranya makna adalah sesuatu yang bersifat intrinsik dari suatu benda, asal-usul makna melihat makna artinya makna berada dalam diri seseorang, makna merupakan ciptaan yang dibentuk melalui interaksi.

- Makna dimodifikasi melalui proses interpretif.

Blumer menyatakan bahwa proses interpretif ini memiliki dua langkah:

Pertama, para pelaku menentukan benda-benda yang mempunyai makna. Ketika seseorang berkomunikasi dengan dirinya sendiri mengenai bagianbagian yang bermakna bagi dirinya. Kedua, pemberian makna sosial berasal dari bagaimana interpretasi secara budaya. Pelaku dapat memilih, mengecek dan transformasi makna dengan bebas. 


\section{Pentingnya Konsep Diri}

Interaksi simbolik juga berfokus pada pentingnya konsep diri. Roger menyatakan karakreristik tentang cirri fisik, peranan, talenta, keadaan emosi, nilai, keterampilan dan keterbatasan sosial, intelektualitas, dan seterusnya membentuk konsep diri. Berikut ini dua asumsi tambahan, menurut LaRossan dan Reitzes:

- Individu-individu mengembangkan konsep diri melalui interaksi dengan orang lain.

Konsep diri dapat berasal dari interaksi sosial. Edgar Burgess salah satu sebagai peneliti awal mengenai keluarga memberikan refleksi bahwa keluarga sebagai institusi untuk bersosialisasi. Menrut Burgees dapat terjadi perselisihan paham mengenai konsep diri anak. Sedangkan Alicia Cast (2003) dalam West \& Turner (2008) berpendapat bahwa tentang diri juga berasal dari konteks sosial dan interaksi sosial.

- Konsep diri memberikan motif yang penting untuk perilaku.

Mead menyatakan bahwa diri berinteraksi dengan dirinya sendiri, sehingga menuntun perilaku dan sikap. Pemenuhan diri (self-fulfilling prophecy), atau prediksi akan diri menghasilkan seseorang untuk berperilaku sehingga harapannya dapat terwujud.

\section{Hubungan antara Individu dan Masyarakat}

Menurut Mead dan Blumer keteraturan dan perubahan dalam proses sosial sebagai berikut (West \& Turner 2008):

- Proses budaya dan sosial mempengaruhi orang dan kelompok.

Perilaku individu dibatasi oleh norma-norma sosial serta perilaku dan sikap yang penting dalam konsep diri dipengaruhi oleh budaya

- Interaksi sosial menghasilkan struktur sosial.

Manusia dapat membuat pilihan ketika melakukan interaksi simbolik, karena situasi sosial dapat dimodifikasi. Contohnya: “Jumat Kasual” yang diterapkan dalam tempat kerja di Amerika Serikat yakni ketentuan bahwa pegawai dapat menggunakan pakaian yang kasual dibandingkan dengan 
hari lainnya sesuai kesepakatan. Manusia dapat membuat pilihan pada saat berinteraksi dan tidak dibatasi.

\section{PEMBAHASAN}

Di dalam kehidupan pasangan suami-isteri adanya WA selain untuk membantu berkomunikasi dengan orang lain dengan waktu yang cepat juga dapat menghasilkan dampak negatif lainnya yaitu dapat memicu kecemburuan, konflik, kurangnya tatap muka dengan pasangan, timbulnya prasangka, dan lain sebagainya. Dahulu sebelum adanya WA atau media sosial internet, hal ini tidak menjadi memicu adanya konflik suami-isteri. Pada kenyataannya WA sudah dapat menjadi pihak ketiga yang menjadikan komunikasi melalui internet lebih intim dibandingkan dengan komunikasi tatap muka, padahal sebagai pasangan suamiisteri komunikasi antarpribadi yang intim merupakan tahapan paling dalam pada komunikasi, karena komunikasi antarpribadi tidak dapat dilakukan kepada setiap orang yang memerlukan suatu usaha dan investasi yang lebih dibandingkan komunikasi lainnya.

Berdasarkan penelitian Widia Asriana dan Yudiana Ratnasari (2012) menunjukkan bahwa internet dapat menghasilkan ketidaksetiaan dan kecemburan antara pasangan dibandingkan ketidaksetiaan sesksual. Dalam perselingkungan emosional wanita lebih cemburu dibandingkan pria, walaupun demikian perbedaannya tidak signifikan siginifikan antara pria dan perselingkuhan seksual pasangan wanita. Penelitian ini bermafaat dalam mendukung efek serius pada hubungan di dunia nyata. Contoh lain dalam media sosial melalui Facebook (FB) juga menyebabkan perceraian seperti yang terjadi pada Anang disebabkan karena kecemburuan melalui tingginya penggunaan HP dan FB. Isteri mempunyai Pria Idaman Lain lebih tinggi dibanding Wanita Idaman Lain. Perceraian terjadi karena keduanya mempunyai PIL dan WIL. Tingginya angka perceraian karena media sosial terjadi di Ciamis (Maulana \& Gumgum 2013).

Berdasarkan artikel Laura Robinson (2007) "The cyberself: the self-ing project goes online, symbolic interaction in the digital age" dia berpendapat bahwa penggunaan perspektif interaksi simbolik untuk membingkai proyek cyberself-ing agar kita 
memahami bentuk dari cyber yaitu pada " $I$ ", " $m e$ " dan "generalized other" digital sebagai dinamika interaksi pada isyarat online.

Ketika individu terhubung dengan WA yang mana merupakan media berinteraksi dengan bebas tanpa ada hambatan diantara keduanya. Pasangan suami isteri yang masing-masing tiap hari lebih banyak berinteraksi dengan orang lain melalui WA menciptakan hubungan simbol dan interaksi antara keduanya. Diantaranya mereka berbagi makna, gambar atau photo, emoticon, dapat melakukan free call, record suara, dan lain sebagainya tanpa adanya batasan waktu, kecuali ketika ada pesan masuk di WhatsApp dan tidak ada feedback, maka tidak terjadi suatu interaksi simbolik, karena tidak ada pemaknaan diantara keduanya.

Fenomena ini menyebabkan suatu perubahan sosial, ketika misalnya suami lebih banyak berinvestasi waktunya melalui WA hanya dengan berkomunikasi dengan teman lama, apakah itu di dalam group, lawan jenis, dengan saudara, atau diskusi melalui WA dengan mudah isterinya akan menduga bahwa suaminya tidak memberikan perhatian dan mengajaknya berkomunikasi. Suami lebih dekat dengan gadget daripada dengan isterinya. Tindakan yang dilakukan suami ini dapat menyebabkan kecemburuan dan buruknya komunikasi antarpribadi karena keduanya. Istri mempunyai prasangka dan persepsi, bahwa suaminya berinteraksi lebih intensif dengan wanita lain daripada dengan pasangannya. Sangat jarang pasangan tersebut membuka diri dengan menginformasikan dengan siapa mereka chatiing, apa yang sedang mereka lakukan dengan gadgetnya atau bertukar gadget. Gadget sudah merupakan ranah pribadi bagi tiap individu, sekalipun mereka pasangan sudah menikah.

Dalam interaksi simbolik dengan lawan jenis, pada suatu waktu bisa saja isteri menemukan foto suaminya dengan teman-teman masa lalunya (ada juga foto dengan teman lawan jenis), tentu si isteri berprasangka buruk apakah maksud dari foto ini tanpa ada komunikasi sebelumnya, sebaliknya suaminya pun tidak memberikan informasi kepada isterinya foto tersebut dan hal apa saja yang dia lakukan dengan gadget-nya. Dalam interaksi simbolik pasangan suami isteri memahami bagaimana pasangannya bersama dengan orang lain, menciptakan dunia simbolik (melaui emoticon, komunikasi nonverbal: feedback tertawa sendiri 
sambil menatap layar, tersenyum, menerima dan mengirim foto, dan memainkan fitur lainnya pada WA) dan bagaimana WhatsApp membentuk perilaku suami atau isteri. Suami atau isteri yang sebelumnya berkomunikasi lebih sering berjalannya waktu intensitas komunikasinya berkurang walaupun masih satu rumah. Suami sudah sibuk membaca pesan-pesan dari WhatsApp dibandingkan untuk bertanya bagaimana keseharian yang telah dilakukan isteri dan sebaliknya. Pengguna WA mempunyai rasa saling ketergantungan antar inidividu WhatsApp dan masyarakat (kontak yang ada di WA). Dalam interaksi simbolik melalui WA membentuk adanya rasa saling ketergantungan di dunia cyber yang merasa bahwa berkomunikasi di dunia cyber jauh lebih penting dan asyik dibandingkan dengan orang sekitarnya.

Matusizt (2007) dalam Maulana \& Gumelar (2013) mengemukakan bahwa terjadi pergeseran cara berkomunikasi dari dampak internet yaitu turunnya afek dengan orang yang menerima pesan seperti tidak adanya sentuhan secara fisiologis, teknologi yang dapat mendistorsi pesan.

Chatting, mengirim emoticon, membaca pesan-pesan WA, mengirim gambar, menerima gambar dan lain sebagainya merupakan gerakan interaksional, saling menjawab pesan dan menerima feedback dari orang lain. WA selain sebagai media sosial juga merupakan tindak sosial, karena pertukaran makna juga dilakukan melalui WA.

Penggunaan WA pada konsep utama dalam teori "Mead "Masyarakat (society), Diri sendiri (self), dan Pikiran (mind)" yaitu:

1. Masyarakat (society)

WA merupakan suatu fenomena masyarakat pada media sosial. Dunia ini terbentuk melalui cyber. Melalui WA setiap orang bebas untuk berekspresi, berkomunikasi mengirimkan simbol-simbol dengan orang lain melalui emoticon, mengirim gambar-gambar tanpa filter dan tanpa batasan waktu. Ketika si suami mengirimkan emoticon kepada teman lawan jenisnya seperti emoticon 'hati', 'tersenyum', 'pemberian hadiah', dan lain sebagainya tentu dapat membuat kecemburuan oleh isterinya, jika isteri mengetahui, 
begitupula sebaliknya. Sehingga pengguna tidak dapat berkomunikasi tanpa berbagi makna dari simbol-simbol yang digunakan satu sama lain.

2. Diri

Diri terbagi menjadi dua (West \& Turner 2008) yaitu: (1) I sebagai diri yang spontan, impulsif, dan kreatif dalam hal ini $I$ ingin untuk selalu berinteraksi dengan teman-teman di WA atau teman lawan jenisnya dalam komunikasi antarpribadi dibandingkan dengan pasangannya, kemudian dalam Me yang bersifat reflektif dan lebih peka secara sosial bahwa lebih berhati-hati dan menyadari bahwa berkomunikasi intim dengan pasangannya jauh lebih baik ketimbang dengan orang lain di dunia cyber yang menguras energi dan waktu. Me mengedepankan pasangan yang sah dalam menjalin komunikasi antarpribadi.

3. Pikiran (mind)

Pada saat chatting melalui WA suami atau isteri mempunyai kemampuan untuk menggunakan simbol yang mempunyai makna yang sama, dan Mead percaya bahwa manusia harus mengembangkan pikiran melalui interaksi dengan orang lain (West \& Turner 2008). Dalam chatting tentu saja ada bahasa-bahasa apakah pantas digunakan dengan lawan jenis seperti kata 'sayang', 'cinta', 'met bobo', dan kata-kata perhatian lainnya yang tidak semestinya digunakan pada saat chatting dengan lawan jenis ketika sudah mempunyai suami atau isteri. Simbol ini mempunyai makna ketika ada katakata tersebut, tentu saja tidak perlu diteruskan dalam komunikasi antarpribadi yang lebih lanjut, karena hal itu sudah menunjukkan suatu anomali dalam kehidupan pasangan suami-isteri yang dapat menyebabkan perceraian dan konflik.

Gejala perubahan sosial dari perspektif teori interaksi dapat dilihat bahwa pasangan suami-isteri dapat bertukar pesan, makna, dan simbol melalui WhatsApp. Sehingga, dampak negatifnya dapat menyebabkan kecemburan, konflik bahkan perceraian ketika pasangan tersebut lebih dekat dengan gadgetnya dibandingkan menjalin komunikasi antarpribadi dengan orang terdekat. Hanya karena asyik 
bermain WhatsApp ketahanan keluarga dapat terancam dan kepercayaan keduanya dapat menurun dibandingkan sebelumnya ketika belum menggunakan whatsApp.

Suami atau isteri secara simbolik dalam WA mengkomunikasikan kehidupannya dengan orang lain, yang mana konsumsi penggunaan gadget yang terlalu intensif dapat ditafsirkan sebagai suatu simbol tersendiri yaitu mengakibatkan hambatan pada komunikasi antarpribadi seperti: kurangnya keterbukaan, kurangnya simpati, kurangnya empati, kurangnya sikap mendukung, tidak adanya kesetaraan, kurangnya perhatian, konflik, hingga perceraian. Dalam interaksi melalui WA dan dengan pasangan suami atau isteri secara langsung, para aktor terlibat dalam proses saling memengaruhi (Ritzer \& Goodman 2004).

Kontribusi teori-teori komunikasi dalam perspektif teori interaksi dalam tulisan ini, yakni Mead menyebut looking-glass-self (kemampuan kita untuk melihat diri kita sendiri dalam pantulan dari pandangan orang lain). Cooley (1972) dalam West \& Turner (2008) meyakini tiga prinsip pengembangan yang dihubungkan dengan cermin diri: (1) bagaimana kita terlihat di mata orang lain. Bagaimana suami atau isteri ketika selalu dekat dengan gagdetnya dilihat oleh pasangannya; (2) bagaimana penilaian mereka mengenai penampilan kita. Suami atau isteri mempunyai pendapat bagaimana penampilan suaminya di mata lawan jenisnya dalam WA, karena waktu untuk bermain WA jauh lebih banyak dan intensif daripada dengan pasangannya; (3) kita merasa tersakiti atau bangga berdasarkan perasaan pribadi ini. Pasangan suami atau isteri belajar mengenai dirinya sendiri dari cara pasangannya dengan memperlakukan, memandang, dan memberi label. Seperti adanya konflik pasangan karena seorang lawan jenis yang mengirin pesan romantis di WA juga bagian dari looking-glass-self.

Di dalam diri juga terdapat konsep diri yang merupakan bagaimana cara individu memandang dirinya dari interaksi dengan orang lain. Konsep diri ini dibangun sejak kecil, seperti ketika dari kecil seorang anak selalu didukung oleh orang tuanya untuk bertindak, maka dia akan belajar percaya diri. Selain itu adanya pengaruh dari generalized others seperti suami atau isteri, orang tua, keluarga dekat, tetangga, sahabat yang dapat membentuk konsep diri individu. Adanya whatsApp juga dapat membentuk konsep diri seseorang secara intens, walaupun generalized 
others oleh suami atau isteri lebih berpengaruh dalam kehidupan pasangan suami isteri. Dalam diri juga terdapat pemenuhan diri (self-fulfilling prophecy) yang bertujuan agar harapannya dapat terwujud. Seperti pada WhatsApp ketika ada sesorang lawan jenis yang memuji suami atau isteri tersebut, seperti "cantik", "baik", "pintar", dan "tampan", maka individu tersebut akan berperilaku sesuai dengan yang dikomunikasikannya.

Sesuai dengan investigasi yang dilakukan Moon \& Nass dalam Werner (2008) dalam Maulana \& Gumelar (2013) mengenai interaksi dengan komputer bahwa seseorang yang terkena terpaan komputer akan merasa berinteraksi "nyata" dengan yang lain artinya kehidupan secara virtual seperti aktif di media sosial adalah nyata, sama halnya tidak di dunia virtual. Semakin tinggi intensitas menggunakan media sosial, maka semakin rendah intensitas komunikasi face to face pada komunikasi antarpribadi (Maulana \& Gumelar 2013). 
Tabel 1. Sebelum dan Sesudah Perubahan Sosial Pada Pasangan Suami-Isteri Melalui WA

\begin{tabular}{|l|l|l|}
\hline Perubahan sosial & Sebelum & Sesudah \\
\hline Apa menjadi apa & Komunikasi antarpribadi tidak \\
melalui smartphone & $\begin{array}{l}\text { Smartphone memudahkan } \\
\text { berkomunikasi dengan siapa } \\
\text { saja dengan orang-orang di } \\
\text { seluruh belahan dunia. }\end{array}$ \\
\hline Culture focuses & $\begin{array}{l}\text { Komunikasi tatap muka jauh } \\
\text { lebih penting antara suami-isteri, } \\
\text { sehingga ada banyak waktu } \\
\text { dengan pasangan. }\end{array}$ & $\begin{array}{l}\text { Pasangan disibukkan dengan } \\
\text { smartphone, sehingga kurangnya } \\
\text { inensitas berkomunikasi tatap } \\
\text { muka dengan pasangan. }\end{array}$ \\
\hline Dampak & $\begin{array}{l}\text { Kepuasan komunikasi pasangan } \\
\text { menikah. }\end{array}$ & $\begin{array}{l}\text { Kurangnya } \\
\text { komunikasi, hilangnya waktu } \\
\text { kualitas komunikasi dengan } \\
\text { pasangan. }\end{array}$ \\
\hline Siapa yang terkena dampak & Pasangan menikah & $\begin{array}{l}\text { Pasangan menikah } \\
\text { Kapan? }\end{array}$ \\
Sebelum berkembangnya & $\begin{array}{l}\text { Sejak } \\
\text { smartphone, mudahnya akses } \\
\text { internet, dan perkembangan } \\
\text { teknologi komunikasi. }\end{array}$ \\
\hline
\end{tabular}

\section{SIMPULAN dan SARAN}

\section{Simpulan}

Berdasarkan hasil analisis dan pembahasan di atas, beberapa simpulan yang dapat ditarik adalah:

1. Teori interaksi simbolik (Symbolic Interaction Theory) menekankan pada hubungan antara simbol dan interaksi yang diberi nama "Mind, Self, and Society", ketiga hal itu juga dimaknai dan dipertukarkan ketika suami atau istri berinteraksi melalui WA dengan orang lain.

2. Gejala perubahan sosial dari perspektif teori interaksi dapat dilihat bahwa pasangan suami-isteri yang semakin dalam berinteraksi melalui WhatsApp dengan wanita atau pria idaman lain akan membuat ketahanan keluarga 
terancam dan kepercayaan keduanya dapat menurun dibandingkan sebelumnya ketika belum menggunakan WhatsApp.

3. Kontribusi teori-teori komunikasi dalam perspektif teori interaksi yakni Mead menyebut looking-glass-self dan konsep diri yang dihasilkan melalui interaksi.

\section{Saran}

Interaksi sosial melalui WA sebaiknya digunakan hanya untuk berkomunikasi kepada orang-orang yang hanya kita butuhkan saja dan yang sangat penting, karena dari segi waktu penggunaan WA dapat mengakibatkan hal yang tidak berguna (membuang-buang waktu). Tentu saja, komunikasi antarpribadi dengan pasangan suami-istri jauh lebih utama dalam mempertahankan ketahanan keluarga dibandingkan mengurangi interaksi dengan pasangan akibat WA.

\section{DAFTAR PUSTAKA}

Asriana ,W., \& Ratnasari Y. (2012). Kecemburuan pada Laki-laki dan Perempuan dalam Menghadapi Perselingkuhan Pasangan Melalui Media Internet. Jurnal Psikologi Pitutur, Volume 1 No.1, Juni 2012, hlm. 81-94

Iskandar, F. (2014). 40\% Kasus Perceraian Seret WhatsApp ke Ruang Sidang, (Online). (http://teknologi.metrotvnews.com/read/2014/11/11/317228/40kasus-perceraian-seret-whatsapp-ke-ruang-sidang, diakses 29 Mei 2015)

Littlejohn, SW. (2009). Teori Komunikasi. Jakarta: Salemba Humanika

Maulana, H, Gumelar, G. (2013). Psikologi Komunikasi dan Persuasi. Bandung: Akademia Pustaka

Ritzer, G. \& Goodman, DJ. (2004). Teori Sosiologi Modern. Edisi ke enam. Jakarta: Kencana

Robinson, L. (2007). The Cyberself: The Self-Ing Project Goes Online, Symbolic Interaction in the Digital Age. New Media \& Society. Vol 9, No. 1: 93-110, (http://nms.sagepub.com/content/9/1/93.abstract)

West, R., Turner, LH. (2008). Pengantar Teori Komunikasi. Analisis dan Aplikasi, Edisi 3. Salemba Humanika: Jakarta

Wood, JT. (2013). Komunikasi Teori dan Praktik (Komunikasi dalam Kehidupan Kita). Jakarta: Salemba Empat 